\section{PERSUASIVE TECHNOLOGY: A SYSTEMATIC REVIEW ON THE ROLE OF COMPUTERS IN AWARENESS STUDY}

\author{
Mohamad Lutfi Dolhalita, Sobihatun Nur Abdul Salamb, Ariffin \\ Abdul Mutalibb
}

aFaculty of Information and Communication Technology, Universiti Teknikal Malaysia Melaka (UTeM), Malaysia bSchool of Multimedia Technology and Communication, Universiti Utara Malaysia (UUM), Malaysia
Article history

Received

9 July 2015

Received in revised form

7 September 2015

Accepted

11 October 2015

*Corresponding author lutfi@utem.edu.my

\section{Graphical abstract}

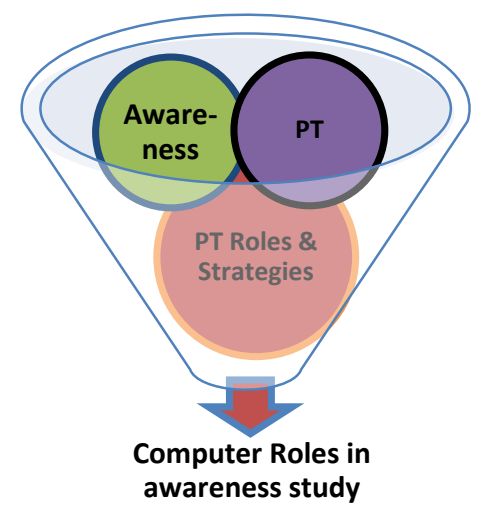

\begin{abstract}
This paper reviews an empirical research of persuasive technology (PT) with the aim are to: (i) examine the result of the 25 persuasive technology studies related to awareness as the intended outcome, (ii) investigate the effects of persuasive technology usage to target users (iii) to examine computer roles in creating awareness to users and the effects of persuasive technology to the domain of studies. The main aim of this review is to assist researchers developing a reference in setting a future research in a persuasive technology particularly in awareness domain. Result from the review indicates that persuasive technology has the ability to increase user awareness toward certain context or issues. Most of the studies shows that the computer as a media and social actor gives more impact to increase the awareness compared to the computer as a tool. It can be concluded that understanding the appropriate persuasive strategy is important in helping researchers developing effective applications towards the intended outcome. This paper also has an implications towards designing persuasive system and as a references for future research.
\end{abstract}

Keywords: Persuasive Technology, Captology, Awareness

\begin{abstract}
Abstrak
Kertas kerja ini adalah berkenaan kajian empirikal teknologi persuasif(PT) dengan tujuan untuk: (i) mengkaji hasil 25 kajian teknologi persuasif berkaitan dengan kesedaran sebagai hasil yang dimaksudkan, (ii) mengkaji kesan penggunaan teknologi persuasif dalam membentuk kesedaran kepada pengguna (iii) mengkaji peranan komputer dalam mewujudkan kesedaran kepada pengguna dan kesan teknologi persuasif kepada domain yang dikaji. Tujuan utama kajian ini adalah untuk membantu para penyelidik membangunkan satu rujukan dalam menjalankan kajian dalam teknologi persuasif terutamanya dalam domain kesedaran. Keputusan kajian menunjukkan bahawa teknologi persuasif berupaya untuk meningkatkan kesedaran pengguna terhadap sesuatu konteks atau isu. Sebahagian besar kajian menunjukkan bahawa komputer sebagai media dan pelakon sosial memberi kesan yang lebih untuk meningkatkan kesedaran berbanding dengan komputer sebagai alat. Dapat disimpulkan bahawa pemahaman terhadap strategi meyakinkan yang sesuai adalah penting dalam membantu penyelidik membangunkan aplikasi yang berkesan ke arah hasil yang dikehendaki. Kertas kerja ini juga mempunyai implikasi ke arah mereka bentuk satu sistem yang meyakinkan dan sebagai rujukan untuk penyelidikan masa depan.
\end{abstract}

Kata kunci: Teknologi Persuasif, Captology, Kesedaran

(C) 2015 Penerbit UTM Press. All rights reserved 


\subsection{INTRODUCTION}

Persuasive technology is a sub-discipline of HumanComputer Interaction [1] and has generated increasing interest in the application of persuasion to systems design. These persuasive applications which the intentional persuasion has been designed into a system are increasingly developed to motivate and provide opportunities for positive change in behaviour.

As elaborated by [2], persuasive technology is defined as the technology designed to change attitudes or behaviors of the users through persuasion and social influence, but not through force and action. Thus, this area of study that explores the overlapping of persuasion and computer technologies is known as Computers as Persuasive Technology or "captology" (Figure 1).

Captology describes the study on how human interact with interactive computers system in which the intended goal of the product were embedded, resulted to change behavior or attitude without using any force or deception [3].

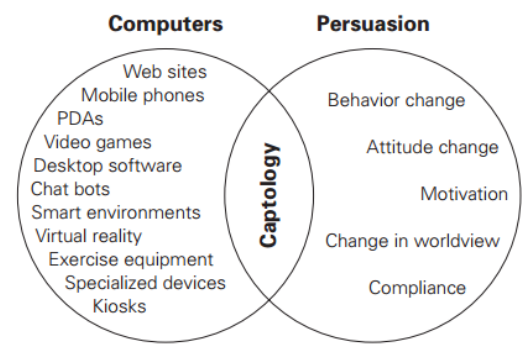

Figure 1 Captology [3]

While the concept of persuasive technology can sometimes comprise a range of definitions, persuasive technologies can also be categorized by whether they change attitude and behaviors through direct interaction or through a mediating role [4].

Thus, in this study, persuasive technology is about how human interact with computers. It means, persuasion occurs at the interface levels of software and hardware where the persuasion is limited to the user and the machine [3] [4].

According to [2], persuasive technology can change people's lives in three related ways based on the functional role, it is; computer as a tool, as a media and or as an actor (Figure 2).

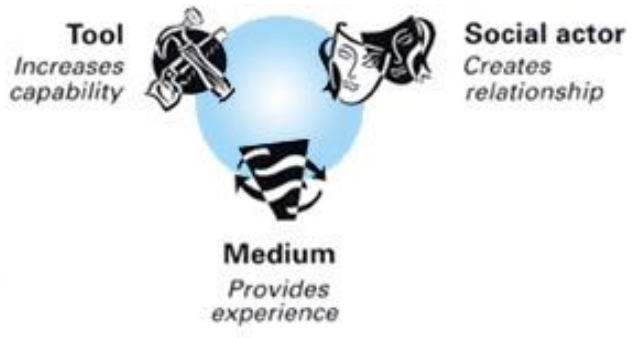

Figure 2 Functional Role of Computer [3]
As a tool, computer can increase people's ability to make target behavior by making it easier to do. As a media, interactive technologies can be used in helping people rehearse their behavior and allowing people exploring the cause-and-effects relationship. While as a social actor, computer can be persuasive by giving a variety of social cues and modelling the target behavior or attitude [2].

A summary of persuasive technology roles and strategies are organized in Table 1:

Table 1 Persuasive Technology Strategy [3]

\begin{tabular}{|c|c|}
\hline $\begin{array}{l}\text { Persuasive } \\
\text { Technology } \\
\text { Roles }\end{array}$ & Persuasion Technique \\
\hline $\begin{array}{l}\text { Computer } \\
\text { as a tool }\end{array}$ & $\begin{array}{ll}- & \text { Principle of Reduction } \\
\text { - } & \text { Principle of Tunneling } \\
\text { - } & \text { Principle of Tailoring } \\
\text { - } & \text { Principle of Suggestion } \\
\text { - } & \text { Principle of Self-Monitoring } \\
\text { - } & \text { Principle of Surveillance } \\
& \text { Principle of Conditioning } \\
\end{array}$ \\
\hline $\begin{array}{l}\text { Computer } \\
\text { as a media }\end{array}$ & $\begin{array}{l}\text { - } \quad \text { Principle of Cause and Effect } \\
\text { - } \quad \text { Principle of Rehearsal } \\
\text { - } \quad \text { Principle of Virtual Rewards } \\
\quad \text { Principle of Simulation in Real-World } \\
\text { Context }\end{array}$ \\
\hline $\begin{array}{c}\text { Computer } \\
\text { as a social actor }\end{array}$ & $\begin{array}{ll}\text { - } & \text { Principle of Attractiveness } \\
\text { - } & \text { Principle of Similarity } \\
\text { - } & \text { Principle of Praise } \\
\text { - } & \text { Principle of Reciprocity } \\
\text { - } & \text { Principle of Authority } \\
\end{array}$ \\
\hline
\end{tabular}

As suggested by [5] multimedia has the potential as a digital persuader as effective as human persuaders which enables behaviour change to a selected target.

Therefore the focus of this study is to:

i. Examine the result of the 25 persuasive technology studies related to awareness as the intended outcome.

ii. Investigate the effects of persuasive technology usage to target users, in term of positive, partially positive or negative/no effects.

iii. Examine computer roles in creating awareness to users and the effects of persuasive technology to the domain of studies.

In this study the definition of awareness as a state in which people are aware of their feelings and behavior in managing and self-control and to achieve the desired outcome by [6] were used. 


\subsection{MATERIALS AND METHODS}

The review process started with the selection of relevant sources for article searches. Springer database was selected as a main database with the search term such as "persuasive technology", "captology", "persuasive multimedia" and "awareness" were searched in titles, abstracts, and keywords. Other than that, IEEE Explore Digital Library and ACM Digital Library were also selected as a secondary database.

At initial searches the Springer database resulted in 1626 article. Whereas for comparisons IEEE database and ACM Digital Library returned only 1459 and 126 articles respectively. Next all the articles were compared to determine any duplication among the search database for exclusion. The tittle and abstract were reviewed independently and the relevant article was selected to determine if they fulfil the criteria. The second part of the review is to screening the content of the article to determine the suitability of the article for this study.

\subsection{Review Criteria}

At the end a result 25 studies related to persuasive technology and awareness related were selected for review. This related article was selected based on the following criteria:

1. The article is an experimental study related to awareness as the outcome of the study.

2. The research methods are explained by the researchers.

3. The studies are related to the effects of persuasive technology to attitude or behavior related to awareness to the selected target.

4. The literature published between 2008 and 2014 from various countries was selected.

\subsection{RESULTS}

\subsection{Category of study}

Table 2 summarizes the result of the reviewed studies. The result is categorized into three types of effects; positive, partially positive and negative or no effects. In summary, a total of 21 studies reported positive results from the persuasive technology treatment in creating and raising awareness to the selected target. This results comprised $80 \%$ of the reviewed studies. While partially positive result were reported in 3 studies comprised $12 \%$, whereas only a few papers discuss the outcome of studies with negative or no effects.
Table 2 Category of studies

\begin{tabular}{llcc}
\hline Result & Study & Total & Percent \\
\hline Positive & {$[7],[8],[10],[11]$,} & 21 & $80 \%$ \\
& {$[12],[19],[14],[16]$,} & & \\
& {$[18],[19],[20],[22]$,} & & \\
& {$[13],[24],[15],[27]$,} & & \\
\hline Partially Positive & {$[28],[29],[30],[31]$} & & $12 \%$ \\
\hline $\begin{array}{l}\text { Negative/No } \\
\text { effects }\end{array}$ & {$[15],[17]$} & 3 & $8 \%$ \\
\hline
\end{tabular}

\subsection{Role of computers}

Table 3 reports the result of the reviewed studies based on the role of computers: (i) as a tools (ii) as media and (iii) as social actor (see Figure 2) as a strategy in creating awareness to the selected target. Overall, from the studies examined, its show the majority of studies employed social actor strategy which encompassed $40 \%$ of the paper reviewed. It also revealed that media simulation is also the most strategies adopted by the researchers comprised $36 \%$ of the studies. While the effects of computer as a tool accounts only $24 \%$ as a strategy applied by the researchers.

Table 3 Roles of computer

\begin{tabular}{llcc}
\hline $\begin{array}{c}\text { Computer } \\
\text { Roles }\end{array}$ & \multicolumn{1}{c}{ Study } & Total & Percent \\
\hline Tool & {$[11],[12],[13],[14]$,} & 12 & $24 \%$ \\
& {$[15],[16],[17],[18]$,} & & \\
\hline Media & {$[20],[23],[25],[27]$,} & & \\
Simulation & {$[7],[8],[9],[10],[11]$,} & 18 & $36 \%$ \\
& {$[14],[18],[20],[21]$,} & & \\
& {$[23],[24],[25],[26]$,} & & \\
& {$[27],[28],[29],[30]$,} & & \\
\hline Social Actor & {$[31],[8],[9],[10],[12]$,} & 20 & $40 \%$ \\
& {$[13],[16],[17],[18]$,} & & \\
& {$[19],[21],[22],[23]$,} & & \\
& {$[24],[26],[27],[28]$,} & & \\
& {$[29],[30],[31]$,} & \\
\hline
\end{tabular}

\subsection{Domain of studies}

Table 4 report the result of the reviewed studies based on the domain of the target behavior of the persuasive technology. Overall, from the studies examined, persuasive technology in health context is the most studied by the researchers encompassed $24 \%$. The second most studied was environmental (20\%) followed by security and safety, conservation and community/social (16\%). Although education and learning are the lowers among the studies, however, implementation of the persuasive learning technique is also embedded in others domain of studies. 
Table 4 Domain of target behavior

\begin{tabular}{|c|c|c|c|}
\hline Domain & Study & Total & Percent \\
\hline Environmental & $\begin{array}{l}{[7], \quad[10],} \\
{[24],[26]}\end{array}$ & 5 & $20 \%$ \\
\hline Security \& Safety & {$[8],[9],[19],[20]$} & 4 & $16 \%$ \\
\hline Conservation & $\begin{array}{lll}{[12],} & {[13],} & {[18],} \\
{[25]} & \end{array}$ & 4 & $16 \%$ \\
\hline Health & $\begin{array}{l}{[14],[15], \quad[20],} \\
{[23],[27],[28],}\end{array}$ & 6 & $24 \%$ \\
\hline Education/Learning & {$[11],[17]$} & 2 & $8 \%$ \\
\hline Community/Social & $\begin{array}{lll}{[21],} & {[29],} & {[30],} \\
{[31]} & \end{array}$ & 4 & $16 \%$ \\
\hline
\end{tabular}

\subsection{DISCUSSION}

The emerging sub-discipline of Human-Computer Interaction ( $\mathrm{HCl})$ : Persuasive technology, gives an opportunity to researchers to implement persuasive design that can potentially bring behaviour or attitude change to the selected target. Referring to the title of this systematic review, where awareness is the main focus on the psychological behavior, it can be concluded that, from the published articles, it indicates that persuasive technology do persuade people to increase their awareness toward certain context or issues. For example, most of the reviewed article shows positive effects of the persuasive system to the users.

Moreover persuasive system can also construct cause-and-effects relationship that help raise user's self-awareness. From this statement it is clear there is potential to apply persuasive technology to enhance positive attitude changes in the interactive system. From the reviewed studies, it also shows a diverse domain of study were discussed by implementing a different type of persuasive strategy.

Although in reality, computer act as a tool in our daily life, however in facilitating the awareness element in the computer system most of the studies show the computer as a media and social actor give more impact to increase the awareness of the respondent.

This study also shows that the effects of persuasive strategy are significantly dependent on the context in which the multimedia element or content is being implemented, as well as on the users who are willing to use the persuasive application and the system. Therefore analyzing the type of persuasive strategy is crucial to the developer to make sure the users will be persuaded and received the intended outcome.

\subsection{CONCLUSION}

Overall, most of the reviewed article showed that persuasive technology can be an effective tool for changing attitudes and learning purposes concerning in creating awareness topics. This review are also provides researchers with in-depth view on how to develop awareness using available principle which could be designed into a persuasive system with the aim to facilitate attitude or behavior to the users. This study are also provides valuable information for future research related to designing of persuasive system that enable designing to engage user to the persuasive computing system.

\section{Acknowledgement}

The authors are momentously obliged to UUM, UTeM, and Malaysian Ministry of Education (MOE) for providing financial assistance through FRGS grant for the research reported in this paper and providing support and facilities that have facilitated the research process along this year.

\section{References}

[1] Mintz, J., \& Aagaard, M. 2012. The Application of Persuasive Technology to educational settings. Educational Technology Research and Development, 60(3): 483-499. doi:10.1007/s1 1423-012-9232-y.

[2] Fogg, B. J. 1999. Persuasive Technologies. Communications of the ACM. 42(5): 26-29.

[3] Fogg, B. J. 2003. Persuasive Technology: Using Computers To Change What We Think And Do. Amsterdam: Morgan Kaufmann Publishers.

[4] Harjumaa, M., \& Oinas-kukkonen, H. 2009. Understanding Persuasive Software Functionality in Practice: A Field Trial of Polar FT60. Proceedings of the 4th International Conference on Persuasive Technology.

[5] Sobihatun Nur, A. S., Wan Ahmad Jaafar, W., \& Azillah, M. A. 2010. Using Persuasive Design Principles In Motivational Feeling Towards Children Dental Anxiety (CDA). Persuasive Technology 2010. 223-237. Retrieved from http://link.springer.com/chapter/10.1007/978-3642-13226-1_23.

[6] Catherine, U. O. 2011. Individual Variables and Principals Emotional Management Competencies in Secondary Schools in Rivers State. Global Academic Group. 1-11.

[7] Centieiro, P., Romão, T., \& Dias, A. E. 2011, November. A Location-Based Multiplayer Mobile Game To Encourage Pro-Environmental Behaviours. In Proceedings of the 8th International Conference on Advances in Computer Entertainment Technology ACM. 31.

[8] Chittaro, L. 2012. Passengers' Safety In Aircraft Evacuations: Employing Serious Games To Educate And Persuade. In Persuasive technology 2012. Design for Health and Safety. Springer Berlin Heidelberg. 215-226.

[9] Chittaro, L., \& Zangrando, N. 2010. The Persuasive Power Of Virtual Reality: Effects Of Simulated Human Distress On Attitudes Towards Fire Safety. In Persuasive Technology 2010. Springer Berlin Heidelberg. 58-69.

[10] Filonik, D., Medland, R., Foth, M., \& Rittenbruch, M. 2013. A Customisable Dashboard Display For Environmental Performance Visualisations. In Persuasive Technology 2013. Springer Berlin Heidelberg. 51-62.

[11] Forget, A., Chiasson, S., van Oorschot, P. C., \& Biddle, R. 2008. Persuasion For Stronger Passwords: Motivation And Pilot Study. In Persuasive Technology 2008. Springer Berlin Heidelberg. 140-150.

[12] Foster, D., Lawson, S., Blythe, M., \& Cairns, P. 2010, October. Wattsup?: Motivating Reductions In Domestic Energy Consumption Using Social Networks. In 
Proceedings of the 6th Nordic Conference on HumanComputer Interaction: Extending Boundaries. ACM. 178187.

[13] Gamberini, L., Spagnolli, A., Corradi, N., Jacucci, G., Tusa, G., Mikkola, E. 2012. Tailoring Feedback To Users' Actions In A Persuasive Game For Household Electricity Conservation. In Persuasive Technology 2012. Design for Health and Safety. Springer Berlin Heidelberg. 100-111.

[14] Gasca, E., Favela, J., \& Tentori, M. 2008. Persuasive Virtual Communities To Promote A Healthy Lifestyle Among Patients With Chronic Diseases. In Groupware: Design, Implementation, and Use. Springer Berlin Heidelberg. 74-82.

[15] Kehr, F., Hassenzahl, M., Laschke, M., \& Diefenbach, S 2012. A Transformational Product To Improve SelfControl Strength: The Chocolate Machine. In Proceedings of the SIGCHI Conference on Human Factors in Computing Systems. ACM. 689-694.

[16] Kim, S., \& Paulos, E. 2010. InAir: Sharing Indoor Air Quality Measurements And Visualizations. In Proceedings of the SIGCHI Conference on Human Factors in Computing Systems. ACM. 1861-1870.

[17] Kim, T., Hong, H., \& Magerko, B. 2010. Design Requirements For Ambient Display That Supports Sustainable Lifestyle. In Proceedings of the 8th ACM Conference on Designing Interactive Systems. ACM. 103-112.

[18] Kuznetsov, S., \& Paulos, E. 2010. UpStream: Motivating Water Conservation With Low-Cost Water Flow Sensing And Persuasive Displays. In Proceedings of the SIGCHI Conference on Human Factors in Computing Systems. ACM. 1851-1860.

[19] Miranda, B., Jere, C., Alharbi, O., Lakshmi, S., Khouja, Y., \& Chatterjee, S. 2013. Examining The Efficacy Of A Persuasive Technology Package In Reducing Texting And Driving Behavior. In Persuasive Technology 2013. Springer Berlin Heidelberg. 137-148.

[20] Burigat, S., \& Chittaro, L. 2014. Designing A Mobile Persuasive Application To Encourage Reduction Of Users' Exposure To Cell Phone RF Emissions. In Persuasive Technology. Springer International Publishing. 13-24.

[21] Reis, S., \& Correia, N. 2011. The Perception of Sound and its Influence in the Classroom. In Human-Computer Interaction-INTERACT 2011. Springer Berlin Heidelberg. 609-626.

[22] Zhang-Kennedy, L., Chiasson, S., \& Biddle, R. 2014. Stop Clicking On "Update Later": Persuading Users They Need Up-To-Date Antivirus Protection. In Persuasive
Technology 2014. Springer International Publishing.. 302322.

[23] Chen, Y. X., Chiang, S. S., Chih, S. Y., Liao, W. C., Lin, S. Y., Yang, S. H. \& Hung, Y. P. 2014. Opportunities for Persuasive Technology to Motivate Heavy Computer Users for Stretching Exercise. In Persuasive Technology 2014. Springer International Publishing. 25-30.

[24] Takayama, C., Lehdonvirta, V., Shiraishi, M., Washio, Y., Kimura, H., \& Nakajima, T. 2009. Ecoisland: A System For Persuading Users To Reduce CO2 Emissions. In Future Dependable Distributed Systems, 2009 Software Technologies for IEEE. 59-63.

[25] Thieme, A., Comber, R., Miebach, J., Weeden, J., Kraemer, N., Lawson, S., \& Olivier, P. 2012. We've Bin Watching You: Designing For Reflection And Social Persuasion To Promote Sustainable Lifestyles. In Proceedings of the SIGCHI Conference on Human Factors in Computing Systems. ACM. 2337-2346.

[26] Valkanova, N., Jorda, S., Tomitsch, M., \& Vande Moere, A. 2013. Reveal-It!: The Impact Of A Social Visualization Projection On Public Awareness And Discourse. In Proceedings of the SIGCHI Conference on Human Factors in Computing Systems. ACM. 3461-3470.

[27] Yahaya, W. A. J. W., Din, R. C., \& Hashim, M. A. 2014. Future Strategy Towards Smoking Cessation: Persuasive Multimedia Application (PMA). In Strengthening Motivation towards Smoking Prevention and Cessation. In GLOBAL HEALTH 2014, The Third International Conference on Global Health Challenges. 37-41.

[28] Ismail, B., Hafiz, M., Ahmad, S. Z., Rosmani, A. F., \& Shuib, N. L. M. 2012. Smoke Shooter: Introducing Danger Of Smoking To School Children With Persuasive Technology. In Humanities, Science and Engineering Research (SHUSER), 2012 IEEE Symposium on. IEEE. 1371-1375.

[29] Yahaya, W. A. J. W., Ahmad, S. N. J., \& Zain, M. Z. M. 2012. Application of Persuasive Multimedia to Raise Stress Awareness among the Secondary School Students. IERI Procedia. 3: 105-113.

[30] Othman, A., \& Yahaya, W. A. J. W. 2012. A Preliminary Investigation: Children's Awareness Of Child Sexual Abuse In Malaysia. International Journal of Social Science and Humanity. 2(3): 242.

[31] Yahaya, W. A. J. W., \& Mohamed Zamri, M. Z. 2014 Abuse of Disabled Parking: Reforming Public's Attitude Through Persuasive Multimedia Strategy. IOP Conference Series: Earth and Environmental Science. 18, 012073. doi:10.1088/1755-1315/18/1/01207. 